第 18 回 日本臨床薬理学会 1997 年 12 月 $11 \sim 12$ 日 東京

\title{
プラシーボ対照試験と実薬対照試験の間で 脳循環代謝改善薬の有効率比較
}

折 笠 秀 樹*

\section{1. 緒 墖}

脳循環代謝改善薬は 1970年頃より開発されてき たが、今再評価としてその有効性が検討されつつあ る。著者らは、プラシーボ対照ランタム化比较試験 (RCT)を対象としたメタアナリシス研究を行った1) その結果は、プラシーボ群の有効率は 17.8\%(16.1〜19.6\%)であり、被験薬群はそれ に比べて8.4\%(4.7〜12.0\%)優れていた。その差 は統計学的にも有意であった。このデータによると 䑈䛻環代謝改善薬の有効率は $26.2 \%$ になるか、そ の数値の妥当性を別のタイプの比较試験、つまり実 薬対照ランタム化比較試験と比较検討した。

2. 方 法

研究対象は脳循環代謝改善菜を扱っており、論文 として出版されている臨床試験とした。しかも、脳 血管障害後遺症、つまり脳卒中後 1 カ月以上の慢性 期の患者を対象とした試験に限定した。加えて、ラ ンタム割り付けを伴っている試験として 36 報の臨 床試験が挙がった。その中で二重盲検ではない試験 が 3 報あり、それらは有効率のデータに関して明ら かにバイアスを含んでいると思われ分析に耐えられ ないため、その 3 報を除く二重盲検ランタム化比較 試験 33 報を対象とした。その中には、同菜だけの Dose-response試験は含めた。

一方、プラシーボ対照試験はプラシーボが対照と なっている試験 14 報が対象である。同様にランタ ム割り付けをしており、プラシーボであるから当然 二重盲検である。試験菜が何Dcseか含む試験も対 象とした。

エンドポイントである有効率は、原則として 8 週 時における有効性評価症例当たりの（著明改善+中

\footnotetext{
* 富山医科薬科大学医学部統計・情報科学 于 930-0194 富山市杉谷 2630
}

等度改善）の割合と定義した。脱落と判定不能は無 効とした。その割合は全体で $4.2 \%$ あった。また、 脱落・判定不能が0例の試験も $39 \%$ あった。 8 週 時の判定が見られないときには最終時等の判定を採 用した。この処置はプラシーボ対照、実薬対照の両 者で共通とした。

3. 結 果

Fig1はプラシーボ対照でのメタアナリシス結果 である。白抜きはプラシーボ群の有効率である。全 体では $17.8 \%(16.1 〜 19.6 \%)$ であった。黒丸は 脳循環代謝改善薬とプラシーボ薬との有効率差を表 す。差は全体として8.4\%(4.7〜 12.0\%)であった。 従って、脳循環代謝改善薬の有効率は $26.2 \%$ とい うことになる。

Fig.2は実薬対照でのメタアナリシス結果である。 白抜きは対照薬群の有効率である。全体では 22.3\%(21.2〜23.4\%) であった。黒丸は被験薬 群と対照薬の有効率差を表す。差は全体として 4.5\%(2.7\%〜 6.2\%)であった。ここでは、被験 薬も対照薬も䐉循環代謝改善薬である。被験薬の推 定有効率は26.8\%であった。プラシーボ対照試験 でのそれが26.2\%であるから、それほど大差ない ことがわかる。

さらに、実菜対照試験33報のValidityを 2 通りの 方法で検証した。まず、用量反応試験(DR)と実薬対 照試験(AC) での有効率の一貫性を検討した。 Nefiracetam(DM-9384)の450mg/dayでは、DRのほうで 44\%、ACのほうで41\%という有効率であった。 TA-3090の30mg/dayでは、DRのほうで34\%、ACの ほうで35\%の有効率であった。第二に、多用され る対照薬ことに試験間での有効率の一致性を見た。 Hopateは8試験で用いられ、その有効率は15 23\%と変動していた。Nicardipine（6試験）の有効 率は18〜30\% と少しばらついているが、Ifenprodil （5試験）の有効率は19〜24\%であった。 Idebenone（3試験）は26〜27\%であった。 


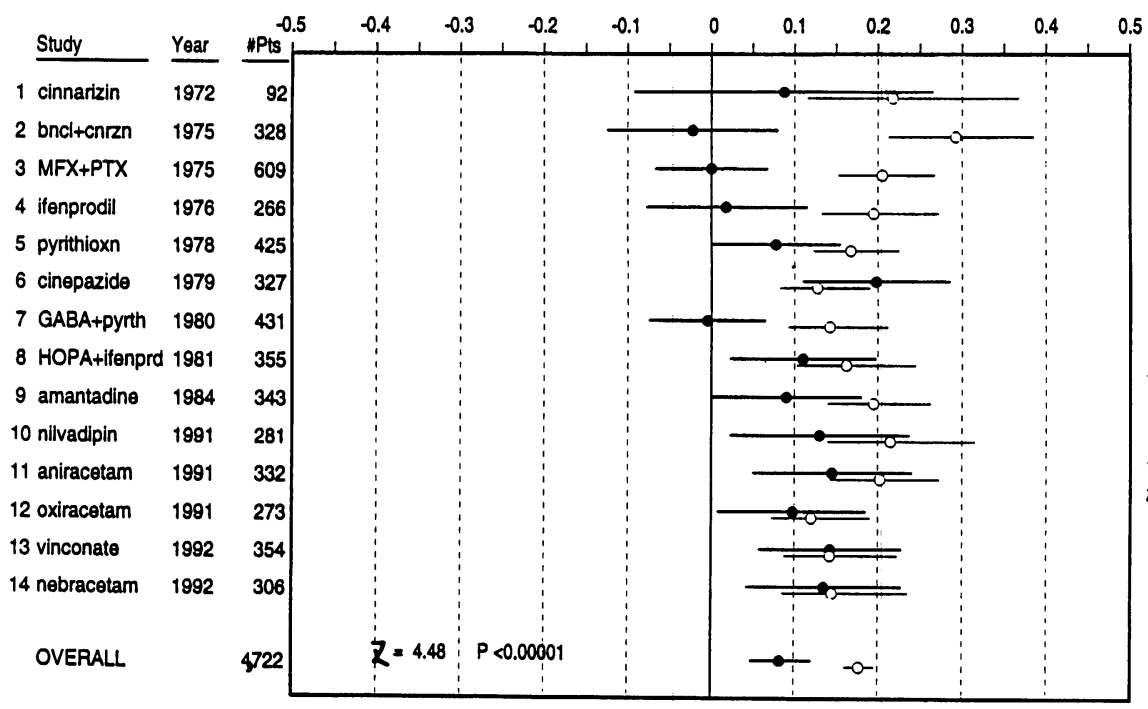

\section{Study}

$\begin{array}{lll}1 & \text { Study } & \text { Year } \\ 2 \text { Cinepazide } & & 1980 \\ 3 \text { Vinpocetine } & 1982 \\ 3 \text { Vinposil } & 1983\end{array}$

4 Mexisylyte 1983

$\begin{array}{lll}5 & \text { Brovincamine } & 1983 \\ 6 & \text { Celliyl } & 1984\end{array}$

7 Idebenone 1985

8 Indeloxazine 1986

9 Pentoxifylin 1986

10 Nimodipine 1986

11 Nicergoline 1986

12 KC-404

13 LS-121

14 Aniracetam 1986

15 Propentotyln 1986

$16 \mathrm{SH}-1072 \quad 1986$

17 Nicergoline 1986

18 Aniracotam 1987

19 Cilostazol

20 NicardipineR 1987

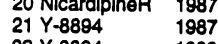

22 Y-8894

24 Minaprine

25 Nivaldipine

26 LS-121 H

27 Oxiracetam

28 TA-3090 LH

29 Nebracetam

30 Vinconate

1992

1994

33 NefiracetamH 1994

OVERALL

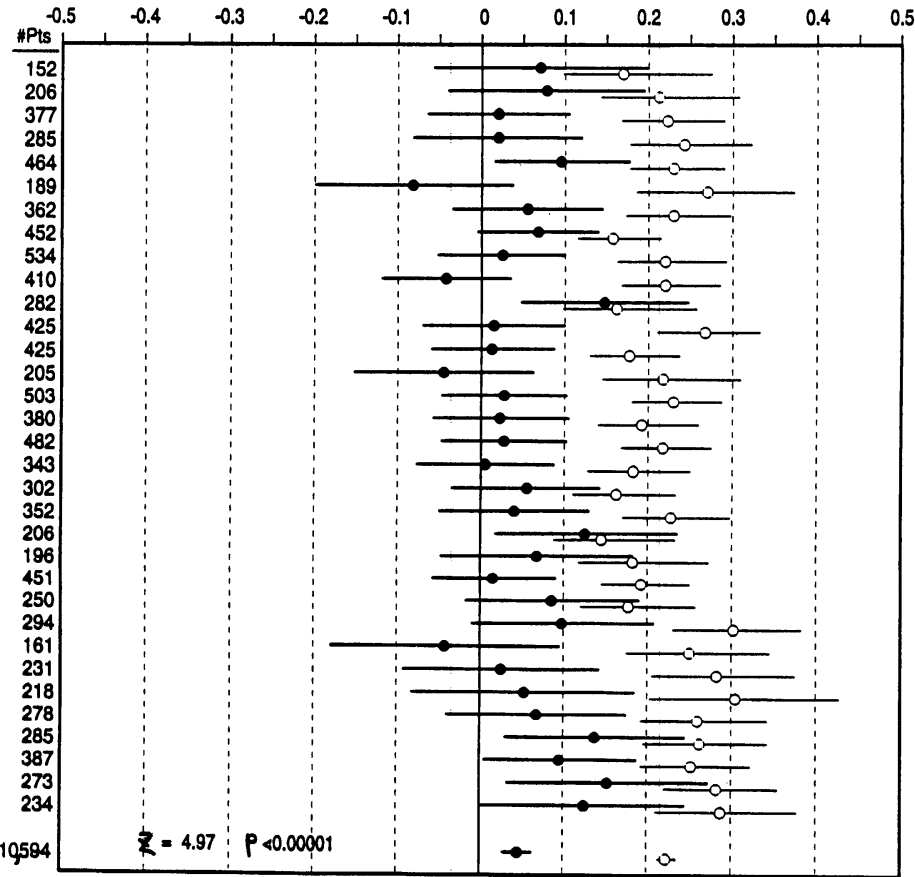

Fig. 2

実薬対照試験 33 報

でのメタアナリシス

結果

白抜きは対照菜群の絶

対有効率を示す。

黒丸は被験蓧と対照菜 との有効率差を表す。 0\%より右側ほど被倹

薬が優れることを表す。 榷は95\%信頼区间を示す。

\section{4. まとめ}

脳循環代謝改善菜のプラシーボ対照試験 14 研究 で4,722症例を含んだ。脳循環代謝改善薬の実薬 対照試験33研究で 10,594症例を含んだ。メタア ナリシスという手法を用いて全体での有効率をそれ ぞれ検討した。プラシーボ対照試験での脳循環代謝 改善薬の有効率は26.2\%であった。実菜対照試験 での被験薬の有効率は $26.8 \%$ と類似していた。ち

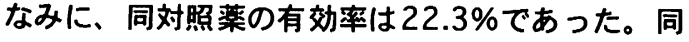

種薬郕の有効率に関する試験間変動もわずかであっ た。近年ほど有効率は高かったが、それは両者(PC, AC)に共通していた。結語として、ランタム化二重 盲検試験に関するかきり、ACとPCの間で結果変数 に関するバイアスは認められなかった。 引用文献

1）勧原幸人，折笠秀樹：メタアナリシスを用いた 脳循環代謝改善菜臨床効果の再検討。脳卒中（印 刷中）,1997. 